\title{
Soybean Genotypes Resistant to Phytophthora sojae and Compensation for Yield Losses of Susceptible Isolines
}

\author{
J. R. Wilcox, Research Geneticist, Crop Production and Pest Control Research Unit, Agricultural Research Service, \\ U.S. Department of Agriculture and Department of Agronomy, Purdue University, West Lafayette, IN 47907-1150, \\ and S. K. St. Martin, Professor, Department of Horticultural and Crop Science, Ohio State University, 2021 Coffey \\ Rd., Columbus, OH 43210-1086
}

\begin{abstract}
Wilcox, J. R., and St. Martin, S. K. 1998. Soybean genotypes resistant to Phytophthora sojae and compensation for yield losses of susceptible isolines. Plant Dis. 82:303-306.

Two isolines, with different alleles for resistance to Phytophthora sojae, of the soybean cultivars, Beeson, Century, and Williams were grown in replicated tests to assess yield losses attributable to this pathogen. Isolines susceptible to prevalent races of the pathogen had black seed coats as a marker trait; isolines resistant to prevalent races of the pathogen had yellow seed coats. Included in the tests were blends composed of equal numbers of seed of the two isolines for each cultivar. Tests were conducted at three locations in Indiana and one location in Ohio for three years. In six environments, where Phytophthora root and stem rot damaged soybean, isolines susceptible to prevalent races of the pathogen produced seed yields from 65 to $93 \%$ of the yields of isolines resistant to these races. In four of these environments, isoline blends produced yields equal to those of the resistant isoline. In two environments, where susceptible isolines averaged 65 and $69 \%$ of the yield of the resistant isoline; the blends averaged 89 and $83 \%$ of the yield of the resistant isoline. Where the pathogen reduced yields of susceptible isolines, yellow seeds of the isoline resistant to prevalent races of the pathogen contributed from 10 to $33 \%$ more seed than would be expected if resistant and susceptible isolines contributed equally to seed yield. The data demonstrate that plants of the resistant isoline were compensating for reduced productivity of the susceptible plants in the blend.
\end{abstract}

Phytophthora root and stem rot, caused by Phytophthora sojae (Kaufmann and Gerdeman), is a destructive disease of soybean (Glycine max (L.) Merr.) in the United States. Wrather et al. (19) estimated that the disease reduced soybean yields by 560,300 metric tons in the United States in 1994. In the North Central States, yield losses due to this pathogen have been estimated at $13 \%$ of total production for each of the years 1989 through 1991 (7).

Yield losses to $P$. sojae have been limited by incorporating into cultivars Rps alleles for resistance to prevalent races of the pathogen. As new races of the pathogen developed, additional Rps alleles were found that protect soybean against these races. Resistance alleles are incorporated into new cultivars, or backcrossed into productive cultivars, to provide soybean producers with adequate protection against the pathogen. During the past 25 years, more than 40 different races of the pathogen have been identified (1). During this

Corresponding author: J. R. Wilcox

E-mail: jwilcox@dept.agry.purdue.edu

Accepted for publication 20 November 1997.

Publication no. D-1997-1219-01R

This article is in the public domain and not copyrightable. It may be freely reprinted with customary crediting of the source. The American Phytopathological Society, 1998. same time, 13 alleles that control resistance to multiple races of the pathogen have been identified at seven different loci (3). Several years are required to incorporate new Rps alleles into high-yielding cultivars, and yield losses due to new $P$. sojae races will continue to occur during resistant cultivar development. Planting blends of lower yielding resistant and higher yielding susceptible cultivars may provide a mechanism to optimize production until high-yielding resistant cultivars are available.

Blends of cultivars or isolines have been used to control losses due to pathogens in several agronomic crops. Yield losses of cereal grains, primarily due to rusts, have been reduced by growing blends of isolines or cultivars with different loci controlling resistance $(6,8,18)$. These blends, or multilines, slow the rate of increase of prevalent races of the pathogen on host plants. Blends of soybean cultivars have been recommended as a strategy to delay shifts of soybean cyst nematode (Heterodera glycines Ichinohe) populations from one race to another in production fields (13). Anand et al. (2) reported that 50:50 blends of soybean cultivars resistant and susceptible to soybean cyst nematode were generally similar in yield to the resistant components and always higher in yield than susceptible components when grown in monoculture.

This study was conducted to evaluate the performance of isoline blends of soy- bean cultivars having different alleles controlling resistance to different races of $P$. sojae. A marker trait for the different components of the blends permitted an accurate assessment of the contribution of each component of the blend to seed yield.

\section{MATERIALS AND METHODS}

Two isolines of the cultivars Beeson, Century, and Williams were included in the study. The isolines differed in alleles for resistance to prevalent races of $P$. sojae. Beeson (9) and Century (15) have the Rps 1-a allele for resistance to races 1, 2, $10,11,13-18,24,26,27,31,32$, and 36 of $P$. sojae (1). Williams (5) has the rps 1 allele that results in susceptibility to all races of the pathogen. Beeson, Century, and Williams all had completely black or imperfect black seed coat color (Sb). The unique black or imperfect black seed coats were due to spontaneous mutations to the $i$ allele at the $I$ locus (17). Seeds with black seed coats had been selected from normal colored seed lots of each of these cultivars. The dark colored seeds of each cultivar were increased for use in this study. The black seed coat served as a neutral marker with respect to seed yield for these isolines (14).

A second isoline, Beeson 80, Century 84 , and Williams 82 , of each of the three cultivars was included in the study. Beeson 80 (16), with the Rps1-c allele, is resistant to races $1-3,6-11,13,15,17,21,23,24$, $26,28-30,32,34,36,41,42$, and 44 of the pathogen (1). Century 84 (12) and Williams 82 (4) have the Rps $1-\mathrm{k}$ allele that confers resistance to races $1-11,13-15,17$, $18,21-24,26,36,37$, and $42-44$ of $P$. sojae (1). These isolines all had the $i^{\mathrm{i}}$ alleles at the $I$ locus and dark pigmentation is restricted to the hilum on seeds, the remainder of the seed coat is yellow (Sy). The yellow seed coat served as a convenient neutral marker for these isolines.

Plots of the six genotypes (Beeson [Sb], Beeson 80 [Sy], Century [Sb], Century 84 [Sy], Williams [Sb], and Williams 82 [Sy]) and three blends, composed of equal numbers of seed of the two isolines of each cultivar, were grown at Bluffton, and Davis, IN, and at Hoytville, OH. P. sojae commonly reduces seed yield of cultivars with the Rps1-a or rps 1 alleles at these locations. Cultivars with the Rps1-c or Rps 1 -k alleles typically do not show dis- 
ease symptoms or reduced seed yield due to $P$. sojae at these locations. Plots of these six genotypes and the blends also were grown at West Lafayette, IN, where yield losses due to this pathogen seldom occur. A split-plot randomized design was used at each location in which main plots were cultivars and three subplots consisted of 1) the black seeded isoline indicating the Rps 1-a or rps alleles for $P$. sojae resistance, 2 ) the yellow seeded isoline indicating the Rps1-c or Rps1-k alleles for resistance, and 3) a blend of equal numbers of black and yellow seed of the two isolines. Each subplot consisted of four rows, $5 \mathrm{~m}$ in length and spaced $0.6 \mathrm{~m}$ apart, at the three Indiana

Table 1. Average seed yields and incidence of yellow and black seeds of isolines with Rps1-c and $R p s 1-\mathrm{k}$ alleles compared to isolines with Rps1-a and rps 1 alleles and isoline blends in environments with no significant yield reductions associated with Phytopthora sojae

\begin{tabular}{|c|c|c|c|}
\hline Test site and isoline components & Yield (kg/ha) & Yellow seeds ${ }^{x}$ (no.) & Black seeds $^{y}$ (no.) \\
\hline \multicolumn{4}{|l|}{ Davis, 1992} \\
\hline$R p s 1-\mathrm{c}$ or $R p s 1-\mathrm{k}$ & $3,252 \mathrm{a}^{\mathrm{z}}$ & 398 & 2 \\
\hline Rps $1-\mathrm{a}$ or $r p s 1$ & $3,282 \mathrm{a}$ & 1 & 399 \\
\hline Blend & $3,072 \mathrm{a}$ & 217 & 183 \\
\hline \multicolumn{4}{|l|}{ Lafayette, 1992} \\
\hline$R p s 1-\mathrm{c}$ or $R p s 1-\mathrm{k}$ & $2,504 \mathrm{a}$ & 399 & 1 \\
\hline$R p s 1-\mathrm{a}$ or $r p s 1$ & $2,467 \mathrm{a}$ & 2 & 398 \\
\hline Blend & $2,440 \mathrm{a}$ & 210 & 190 \\
\hline \multicolumn{4}{|l|}{ Lafayette, 1993} \\
\hline Rps $1-\mathrm{c}$ or Rps $1-\mathrm{k}$ & $4,231 \mathrm{a}$ & 394 & 6 \\
\hline Rps $1-\mathrm{a}$ or $r p s 1$ & $4,070 \mathrm{a}$ & 5 & 395 \\
\hline Blend & $4,199 \mathrm{a}$ & 221 & 179 \\
\hline \multicolumn{4}{|l|}{ Lafayette, 1994} \\
\hline$R p s 1-\mathrm{c}$ or $R p s 1-\mathrm{k}$ & $3,142 \mathrm{a}$ & 397 & 3 \\
\hline$R p s 1-\mathrm{a}$ or $r p s 1$ & $3,016 \mathrm{a}$ & 6 & 394 \\
\hline Blend & $3,192 \mathrm{a}$ & 201 & 199 \\
\hline \multicolumn{4}{|l|}{ Hoytville, 1992} \\
\hline$R p s 1-\mathrm{c}$ or $R p s 1-\mathrm{k}$ & 3,317 a & 399 & 1 \\
\hline Rps $1-\mathrm{a}$ or $r p s 1$ & $3,314 \mathrm{a}$ & 0 & 400 \\
\hline Blend & $3,309 \mathrm{a}$ & 203 & 197 \\
\hline
\end{tabular}

Table 2. Average seed yields and incidence of yellow and black seeds of isolines with Rps1-c and $R p s 1-\mathrm{k}$ alleles compared to isolines with Rps1-a and rps 1 alleles and isoline blends in environments with significant yield reductions associated with Phytopthora sojae

\begin{tabular}{|c|c|c|c|}
\hline Test site and isoline components & Yield (kg/ha) & Yellow seeds ${ }^{x}$ (no.) & Black seeds ${ }^{y}$ (no.) \\
\hline \multicolumn{4}{|l|}{ Bluffton, 1993} \\
\hline$R p s 1-\mathrm{c}$ or $R p s 1-\mathrm{k}$ & $2,499 \mathrm{a}^{\mathrm{z}}$ & 398 & 2 \\
\hline Rps $1-\mathrm{a}$ or $r p s 1$ & $1,908 \mathrm{~b}$ & 3 & 397 \\
\hline Blend & $2,133 \mathrm{~b}$ & 249 & 151 \\
\hline \multicolumn{4}{|l|}{ Bluffton, 1994} \\
\hline Rps1-c or Rps1-k & $2,684 \mathrm{a}$ & 398 & 2 \\
\hline Rps $1-\mathrm{a}$ or $r p s 1$ & $1,991 \mathrm{c}$ & 3 & 397 \\
\hline Blend & $2,422 \mathrm{~b}$ & 266 & 134 \\
\hline \multicolumn{4}{|l|}{ Davis, 1993} \\
\hline Rps1-c or Rps1-k & $3,418 \mathrm{a}$ & 397 & 3 \\
\hline Rps $1-\mathrm{a}$ or $r p s 1$ & $2,603 \mathrm{~b}$ & 4 & 396 \\
\hline Blend & $3,356 \mathrm{a}$ & 259 & 141 \\
\hline \multicolumn{4}{|l|}{ Davis, 1994} \\
\hline Rps1-c or Rps $1-\mathrm{k}$ & $3,541 \mathrm{a}$ & 399 & 1 \\
\hline Rps $1-\mathrm{a}$ or $r p s 1$ & $3,141 \mathrm{~b}$ & 5 & 395 \\
\hline Blend & 3,484 a & 229 & 171 \\
\hline \multicolumn{4}{|l|}{ Hoytville, 1993} \\
\hline$R p s 1-\mathrm{c}$ or Rps $1-\mathrm{k}$ & $1,997 \mathrm{a}$ & 399 & 1 \\
\hline Rps $1-\mathrm{a}$ or $r p s 1$ & $1,767 \mathrm{~b}$ & 2 & 398 \\
\hline Blend & $1,914 \mathrm{a}$ & 261 & 139 \\
\hline \multicolumn{4}{|l|}{ Hoytville, 1994} \\
\hline Rps $1-\mathrm{c}$ or Rps $1-\mathrm{k}$ & $3,605 \mathrm{a}$ & 399 & 1 \\
\hline Rps $1-\mathrm{a}$ or $r p s 1$ & $3,374 \mathrm{~b}$ & 3 & 397 \\
\hline Blend & $3,610 \mathrm{a}$ & 219 & 181 \\
\hline
\end{tabular}

locations. Rows were end-trimmed to 3.7 $\mathrm{m}$ in length prior to maturity and the center two rows harvested for seed yield. At Hoytville, $\mathrm{OH}$, subplots consisted of six rows $5 \mathrm{~m}$ in length with a $0.38 \mathrm{~m}$ spacing between rows. These plots were endtrimmed to $3.4 \mathrm{~m}$ prior to maturity and the center four rows harvested for seed yield. Each subplot at all locations was seeded with 450 seeds of each entry in the test. Six replications were grown at each location in each of 3 years of the test. Planting dates were between 11 and 23 May for the various locations in the 3 years of the tests.

During the growing seasons, observations were made of stunted and diseased plants with stem lesions symptomatic of Phytophthora root and stem rot. After harvest, data were recorded on seed yield as grams per plot and converted to kilograms per hectare before analyses. The number of black and yellow seeds in a 400-seed sample from each subplot in each replication was recorded. Analyses of variance were computed on data for each of the traits measured at each location for each year. After preliminary analyses of data, environments were placed in one of two fixed classes, disease present or disease absent. Within each of these classes, environments were considered random effects in the data analyses.

\section{RESULTS}

No data were recorded from the Bluffton location in 1992 because excessive rainfall resulted in ponding in the plot area and loss of many of the plots.

No plants were observed that exhibited symptoms of Phytophthora root and stem rot at any location in 1992 or at West Lafayette in any year of the tests. There were no significant differences in seed yields between isolines susceptible and resistant to $P$. sojae races at these locations (Table 1). Plots planted to blends of the isolines were similar in yield to the isoline components of the blends in these five environments. There were no significant differences in numbers of yellow and black seeds harvested from plots planted to blends of the isolines in each of these environments, except West Lafayette in 1993. In this environment, there were $10.5 \%$ more yellow seeds of the Rps 1-c and Rps1$\mathrm{k}$ isolines than the expected 200:200 ratio.

At six test location-year combinations (environments), yields of the Rps 1 -a and rps isolines were significantly lower than yields of the Rps $1-\mathrm{c}$ and Rps1-k isolines (Table 2). Plants with typical Phytophthora root and stem rot symptoms were observed in these environments. Analyses of variance demonstrated that the interaction of variety $\times$ subplot component (blackseeded, yellow-seeded, blend) for seed yield was not significant in five of the six environments, which indicates that the differences in yields among the isolines and blends were consistent across environments. 
At Davis and Hoytville, yields of the blends were similar to yields of the Rps $1-\mathrm{c}$, Rps1-k isolines in 1993 and 1994. At Bluffton in 1993, the yield of the blend was not significantly different from the mean yield of the Rps1-a, rps 1 isolines. At this location in 1994, yield of the blend was intermediate to yields of the yellow- and blackseeded isolines. In each of these environments, except Hoytville in 1994, harvested seeds of the blends had significantly more yellow seeds (Rps1-c or Rps1-k isolines) than black seeds (Rps1-a or rps 1 isolines). This demonstrates that in the blends, plants of isolines with the Rps 1-c or Rps 1-k alleles were contributing considerably more to seed yield than were plants with the Rps 1 -a or $r p s 1$ alleles.

Yield reductions due to $P$. sojae were different for isolines and blends of isolines for the three cultivars. The pathogen reduced yields of Century and Williams by $14 \%$ in environments where these isolines were significantly lower in yield than Century 84 and Williams 82 (Table 3). Isoline blends of these two cultivars were similar in yield to the cultivar containing the Rps1-k allele. Beeson, with the Rps1-a allele, produced only $65 \%$ of the yield of Beeson 80 with the Rps1-c allele. The blend of the two isolines of Beeson averaged $11 \%$ lower in seed yield than Beeson 80.

Compensation of the Rps1-c, Rps $1-\mathrm{k}$ components for seed yield of the Rps $1-\mathrm{a}$, rps 1 components in the blends is also shown by the ratio of yellow to black seeds in blends of the three cultivars (Table 4). The Beeson blend had 35\% more yellow seeds than the expected 200:200 ratio. In environments with no observable disease symptoms, the Beeson blend produced $12 \%$ more yellow seeds than the expected ratio. The difference of $23 \%$ in incidence of yellow seeds in environments with significant yield reductions compared to environments with no yield reductions due to the pathogen may be the most accurate estimate of the contribution of Rps1-c and Rps $1-\mathrm{k}$ plants in the blend. Similar calculations determine that the Century 84 isoline contributed $19 \%$ and the Williams 82 isolines $14 \%$ more seeds than would be expected with no $P$. sojae yield reductions. This compares with 22,11 , and $12 \%$ increases in seed yield of the respective blends compared to the isolines with the Rps1-a or rps 1 alleles.

\section{DISCUSSION}

Data from five environments, all locations in 1992 and from West Lafayette in each year of the study, suggest that Phytophthora root and stem rot was not severe enough to affect yields of the isolines with either the Rps1-a or rps 1 alleles. Another possibility is that prevalent races of the pathogen in these environments affected isolines with different alleles for resistance equally. However, the absence of any visi- ble disease symptoms on plants suggests that the pathogen was not affecting plant growth or seed yield in these environments.

Averaged across all test environments where $P$. sojae reduced yields of isolines with the Rps1-a or rps 1 alleles, the isolines with the Rps1-c or Rps 1-k alleles produced $499 \mathrm{~kg} \mathrm{ha}^{-1}$ or $20 \%$ greater seed yield than isolines with the Rps1-a or rps 1 alleles. The blend averaged $361 \mathrm{~kg} \mathrm{ha}^{-1}$ or $14 \%$ greater yield than the isolines with the Rps1-a or rps 1 alleles. We would have expected the yields of the blends to average $2,796 \mathrm{~kg} \mathrm{ha}^{-1}$, intermediate to yields of the component isolines, if $P$. sojae simply reduced yields of the Rps 1 -a and $r p s 1$ components of the blend. However, plants with the Rps1-c or Rps1-k alleles compensated for the yield reduction of plants with the Rps1-a or rps 1 alleles, as shown by the significant increase in yield of the blend above the mean of the two components.

A 1993 survey reported that race 1 represented $31 \%$ of isolates and race 3 represented $26 \%$ of isolates of $P$. sojae found in Indiana (1). This survey also reported that races $4,6-9,13,28$, and 29 each constituted $2-6 \%$ of isolates found in the state. The Rps $1-\mathrm{a}$ allele in Beeson and Century would not have protected these cultivars against races 3, 4, 6-9, 28, and 29 of the pathogen. An Ohio survey reported that races $1,3,4,7$, and 9 were the most prevalent races of $P$. sojae in 1990 and 1991 (10). All but race 1 are virulent on both Beeson and Century. The susceptibility of Beeson and Century to prevalent races of $P$. sojae could account for the reduced yields of the two cultivars in these tests. Williams is susceptible to all races of the pathogen.
The Rps $1-\mathrm{k}$ allele in Century 84 and Williams 82 protects these cultivars against all prevalent races of $P$. sojae in Indiana except races 28 and 29. These two races represented a small percentage of races identified in the Indiana survey (1). The Rps $1-\mathrm{k}$ allele protects these cultivars against races $1,3,4,7$, and 9 , the most prevalent races identified in the Ohio survey (10). However, the Ohio survey reported that 11.7 and $18.5 \%$ of the P. sojae races identified in 1990 and 1991, respectively, could defeat Rps1-k. Resistance to most of the prevalent races of $P$. sojae in both Indiana and Ohio undoubtedly was responsible for the high yields of the resistant isolines of these cultivars in this study.

Beeson 80, with the Rps 1 -c allele, is susceptible only to race 4 of prevalent races of the pathogen in both Indiana and Ohio. Resistance to prevalent races of the pathogen would account for the high yields of this cultivar compared to the susceptible isoline. P. sojae reduced yields of the susceptible isoline of Beeson more than yields of the susceptible isoline of the other two cultivars. Apparently, plants with the Rps1c allele were not compensating for the reduced productivity of plants with the Rps $1-\mathrm{a}$ allele in the Beeson blend to the same extent as in the Century and Williams blends. Beeson has been reported to be less tolerant to $P$. sojae than either Century or Williams (11). Effects of the pathogen may have been severe enough in Beeson that resistant plants could not fully compensate for yield reductions of susceptible plants in the blend.

These data demonstrate that isolines resistant to prevalent races of $P$. sojae compensate, either partially or in full, for re-

Table 3. Yields of isolines with Rps1-c and Rps1-k alleles compared with isolines with Rps1-a and $r p s 1$ alleles and blends of the isolines of three soybean cultivars

\begin{tabular}{|c|c|c|c|c|}
\hline Isoline or blend & Beeson (kg/ha) & Century (kg/ha) & Williams (kg/ha) & Mean \\
\hline \multicolumn{5}{|c|}{ Environments with no significant yield reductions due to Phytopthora sojae } \\
\hline$R p s 1-\mathrm{c}$ or Rps $1-\mathrm{k}$ & $2,949 \mathrm{a}^{\mathrm{z}}$ & $3,222 \mathrm{a}$ & $3,696 \mathrm{a}$ & $3,289 \mathrm{a}$ \\
\hline Rps $1-\mathrm{a}$ or $r p s 1$ & $2,891 \mathrm{a}$ & $3,154 \mathrm{a}$ & $3,644 \mathrm{a}$ & $3,230 \mathrm{a}$ \\
\hline Blend & $2,908 \mathrm{a}$ & $3,204 \mathrm{a}$ & $3,615 \mathrm{a}$ & $3,242 \mathrm{a}$ \\
\hline \multicolumn{5}{|c|}{ Environments with significant yield reductions due to $P$. sojae } \\
\hline$R p s 1-\mathrm{c}$ or $R p s 1-\mathrm{k}$ & $2,732 \mathrm{a}$ & $2,918 \mathrm{a}$ & $3,368 \mathrm{a}$ & $3,045 \mathrm{a}$ \\
\hline Rps $1-\mathrm{a}$ or $r p s 1$ & $2,023 \mathrm{c}$ & $2,554 \mathrm{~b}$ & $2,942 \mathrm{~b}$ & $2,546 \mathrm{~b}$ \\
\hline Blend & $2,471 \mathrm{~b}$ & $2,844 \mathrm{a}$ & $3,284 \mathrm{a}$ & $2,907 \mathrm{a}$ \\
\hline
\end{tabular}

${ }^{\mathrm{z}}$ Means followed by the same letter do not differ at the 0.05 probability level.

Table 4. Ratio of yellow (Rps1-c or Rps1-k) to black (Rps1-a or rps1) seeds in isolines and blends of three soybean cultivars

\begin{tabular}{|c|c|c|c|c|}
\hline Isoline or blend & Beeson (no.) ${ }^{\mathrm{z}}$ & Century (no.) & Williams )no.) & Mean (no.) \\
\hline \multicolumn{5}{|c|}{ Environments with no significant yield reductions due to Phytopthora sojae } \\
\hline Rps $1-\mathrm{c}$ or Rps1-k & $396: 4$ & $398: 2$ & $398: 2$ & $397: 3$ \\
\hline Rps1-a or rps 1 & 3:397 & 3:397 & $2: 398$ & 3:397 \\
\hline Blend & 224:176 & 210:190 & 200:200 & 211:189 \\
\hline \multicolumn{5}{|c|}{ Environments with significant yield reductions due to $P$. sojae } \\
\hline Rps $1-\mathrm{c}$ or $R p s 1-\mathrm{k}$ & 399:1 & 398:2 & 398:2 & 398:2 \\
\hline Rps 1 -a or rps 1 & 3:397 & 4:396 & 3:397 & 3:397 \\
\hline Blend & 270:130 & 248:152 & 226:174 & 248:152 \\
\hline
\end{tabular}

${ }^{\mathrm{z}}$ Average number of seeds based on a 400 -seed sample from each plot at each location. 
duced yields of susceptible isolines when grown in blends. Compensation is due to resistant plants effectively utilizing light, soil moisture, and nutrients underutilized by diseased plants in the blend. The information may be useful in minimizing disease losses associated with new races of the pathogen where alleles for resistance are not available in high-yielding cultivars. Blends of high-yielding, susceptible cultivars and lower-yielding, resistant cultivars may provide the best opportunity to optimize seed yield. In environments where disease pressure is nonexistent or minimal, the high-yielding, susceptible component could compensate for the lower-yielding, resistant component of the blend. Where prevalent races of the pathogen reduced yields of the susceptible component, the resistant component of the blend could partially compensate for these yield reductions.

\section{ACKNOWLEDGMENTS}

Contribution of the Agricultural Research Service, U.S. Department of Agriculture, in cooperation with the Purdue University Agricultural Research Programs, West Lafayette, IN. Journal Paper no. 15471 of the Purdue Univ. Agric. Res. Programs. Supported in part by Public Varieties of Indiana and the Indiana Soybean Development Council.

\section{LITERATURE CITED}

1. Abney, T. S., Melgar, J. C., Richards, T. L., Scott, D. H., Grogan, J., and Young, J. 1997. New races of Phytophthora sojae with Rps1-d virulence. Plant Dis. 81:653-655.

2. Anand, S. C., Koenning, S. R., and Sharma, S. B. 1995. Performance of blends of soybean cyst nematode resistant and susceptible cultivars. Crop Sci. 35:524-528.

3. Anderson, T. R., and Buzzell, R. I. 1992. Inheritance and linkage of the Rps 7 gene for resistance to Phytophthora rot of soybean. Plant Dis. 76:958-959.

4. Bernard, R. L., and Cremeens, C. R. 1988. Registration of 'Williams 82' soybean. Crop Sci. 28:1027-1028.

5. Bernard, R. L., and Lindahl, D. A. 1972. Registration of Williams soybean. Crop Sci. 12:716.

6. Browning, J. A., and Frey, K. J. 1969. Multiline cultivars as a means of disease control. Annu. Rev. Phytopathol. 7:355-382.

7. Doupnik, B., Jr. 1993. Soybean production and disease loss estimates for North Central United States from 1989 to 1991. Plant Dis. 77:1170-1171.

8. Jensen, N. F. 1952. Intra-varietal diversification in oat breeding. Agron. J. 44:30-34.

9. Probst, A. H., Laviolette, F. A., Athow, K. L., and Wilcox, J. R. 1969. Registration of Beeson soybeans. Crop Sci. 9:523-524.

10. Schmitthenner, A. F. 1994. Phytophthora sojae races in Ohio over a 10-year interval. Plant Dis. 78:269-276.

11. Walker, A. K., and Schmitthenner, A. F. 1984.
Comparison of field and greenhouse evaluations for tolerance to Phytophthora rot in soybean. Crop Sci. 24:487-489.

12. Walker, A. K., Schmitthenner, A. F., Fioritto, R. J., St. Martin, S. K., Cooper, R. L., and Martin, R. J. 1986. Registration of 'Century 84' soybean. Crop Sci. 26:199-200.

13. Wallace, M. K., Orf, J. H., and Stienstra, W. C. 1995. Field population dynamics of soybean cyst nematode on resistant and susceptible soybeans and their blends. Crop Sci 35:703-707.

14. Wilcox, J. R. 1988. Performance and use of seedcoat mutants in soybean. Crop Sci. 28:3032.

15. Wilcox, J. R., Athow, K. L., Abney, T. S., Laviolette, F. A., and Richards, T. L. 1980 Registration of Century soybean. 1980. Crop Sci. 20:415.

16. Wilcox, J. R., Athow, K. L., Laviolette, F. A., Abney, T. S., and Richards, T. L. 1980. Registration of Beeson 80 soybean. Crop Sci. 20:414.

17. Williams, L. F. 1945. Off-colored seeds in the Lincoln soybean. Soybean Dig. 5:50-61.

18. Wolfe, M. S. 1985. The current status and prospects of multiline cultivars and variety mixtures for disease resistance. Annu. Rev. Phytopathol. 23:251-273.

19. Wrather, J. A., Anderson, T. R., Arsyad, D. M., Gai, J., Ploper, L. D., Porta-Puglia, A. Ram, H. H., and Yorinori, J. T. 1997. Soybean disease loss estimates for the top 10 soybean producing countries in 1994. Plant Dis. 81:107-110. 